Review

\title{
A Theoretical Analysis of Chinese Ingratiation
}

\author{
Kwok Kuen Tsang \\ School of Social Sciences, Caritas Institute of Higher Education, Hong Kong, China
}

Article history

Received: 26-03-2015

Revised: 09-10-2015

Accepted: 21-10-2015

Email: gkk1212@gmail.com

\begin{abstract}
Literature about ingratiation has mainly focused on non-Chinese societies with a Western viewpoint, which regards ingratiation as an attraction-seeking behavior. However, the viewpoint may not reflect accurately the meanings of ingratiation in Chinese societies, because ingratiation is a culture-specific behavior. Therefore, there is a limited understanding about the natures, motives, consequences and patterns of Chinese ingratiation. Since Chinese ingratiation is an everyday and everywhere occurrence affecting every social actor in Chinese societies, it is necessary to pay much attention to Chinese ingratiation. Therefore, this article attempts to theoretically analyze Chinese ingratiation from the guanxi perspective and then propose a theoretical framework of Chinese ingratiation for further studies. According to the guanxi perspective, Chinese ingratiation is regarded as a guanxi management strategy and defined as a set of social behaviors designed to establish, maintain and promote guanxi through the exercises of renqing, mianzi and attraction. Moreover, this article proposes Chinese ingratiation has three dimensions: renqing orientation, mianzi orientation and attraction orientation. Finally, the pattern of Chinese ingratiation is identified as the follows: (1) The ingratiatory intention decreases progressively along the direction from familiar persons to family and then to strangers in normal situations and (2) renqing and mianzi orientations would be more likely to occur than attraction orientation within familiar persons; attraction and mianzi orientations would be more likely to occur than renqing orientation within family; attraction orientation would be more likely to occur than renqing and mianzi orientations within strangers.
\end{abstract}

Keywords: Ingratiation, Guanxi, Renqing, Mianzi, Attraction

\section{Introduction}

Ingratiation is a significant social behavior that influences our social lives. For example, in his famous book, How to Win Friends and Influence People, Carnegie (1936) details how different ingratiatory strategies help people make friends with others, build good interpersonal relationships and manage good social impression. Although the positive effects of ingratiation to interpersonal relationships have been realized, systemic and scientific investigations on ingratiation have been limited until 1960s (Rosenfeld et al., 1995). Jones (1964) published the first scientific research on ingratiation from a social psychological perspective. Since then, the phenomenon of ingratiation has drawn social scientists' attentions. Nevertheless, the scientific investigations on ingratiation in Chinese societies (Chinese ingratiation) has been scarce (Tsang, 2014). The lack of investigations does not mean Chinese ingratiation is not common. On the contrary, it should be a kind of usual social behaviors among Chinese actors (Aryee et al., 1993; Tsang et al., 2013). This observation is reflected by the idea of social orientation used by K.S. Yang to describe the Chinese characteristic. He writes:
"a predisposition toward such behavior patterns as social conformity, non offensive strategy, submission to social expectations and worry about external opinions in an attempt to achieve one or more of the purposes of reward social acceptance and avoidance of punishment, embarrassment conflict, rejection, ridicule and retaliation in social situation" (Yang, 1981, p. 159).

From the description, it is identified that the behavioral pattern of social orientation to some extent is ingratiatory. For example, the behaviors like flattering, 
compliment, conformity, banquet and gift-giving have been very recognized as ingratiatory practices in the literature (Tsang, 2014). Moreover, Zhai (2011) notes that Chinese ingratiation may lead to many social problems such as corruption. Thus, it is necessary for social scientists to take much effort to study the phenomenon of Chinese ingratiation.

As a result, this article intends to theoretically analyze Chinese ingratiation, because the theoretical analysis can generate a theoretical and hypothetic framework for further studies. Such a framework is important for researchers on Chinese ingratiation because it can provide theoretical ideas, hypotheses and directions for them to study the phenomenon as a starting point. In the following, the article will first discuss how scholars commonly understand ingratiation in the literature and the limitations of the understanding. Then, the article will analyze Chinese ingratiation from the guanxi perspective. The analysis here is based on the guanxi perspective because this perspective provides indigenous concepts as conceptual and analytical tools to understand Chinese social and behavioral phenomena (Tsang, 2011).

\section{Ingratiation: The General Understandings in the Literature}

If everyone reads Social Psychology textbooks (e.g., Myers, 2013), he or she will get a general definition of ingratiation: Ingratiation is an attempt to make oneself become more likeable and attractive. However, this definition may be too general and even simplify the meanings of ingratiation, because ingratiation is a multidimensional construct, which lead to a number of debates in the literature.

The first debate is about the nature of ingratiation, which is whether ingratiation is an immoral, manipulative and deceitful behavior. According to Jones, ingratiation can be defined "a class of strategic behavior illicitly designed to influence a particular other person concerning the attractiveness of one's personal qualities" (1964, p. 11). This definition implies that ingratiation can also be viewed as manipulative and deceitful (Bohra and Pandey, 1984). Similarly, Tedeschi and Melburg (1984) define ingratiation as a set of assertive tactics that organizational members used to gain the approbation of their superiors. However, some people dissatisfy that ingratiation is immoral, manipulative and deceitful. They claim ingratiation is only an attempt for people to increase their attractiveness in the eyes of others (Liden and Mitchell, 1988). Therefore, engaging in ingratiation can be purely due to the desire for becoming attractive (Strutton et al., 1996; Varma et al., 2006).

In addition, another debate to bring out is about the ingratiatory tactics. Ingratiatory tactics refer to the behaviors people actually perform to ingratiate target persons. Different scholars have discovered different tactics. Jones and Wortman (1973) present four common tactics. They are other-enhancement, opinion conformity, rendering favor and self-presentation. Moreover, Pandey (1981; Bohra and Pandey, 1984) discover another four in India, including name-dropping, situation-specific behavior, instrumental dependency and self-depreciation. In addition, Strutton and his colleagues find that the salespeople tend to use the tactics like that in court and counsel, attitudinal conformity, behavioral conformity and self-promotion to their customers (Strutton and Pelton, 1998; Strutton et al., 1995; 1996). In his theoretical discussion, Cooper (2005) suggests joking and humor should be considered as ingratiatory tactics. Moreover, Tsang (2015) show modesty may also be an ingratiatory tactics for Hong Kong youths.

In contrast with the nature and the tactics of ingratiation, there are a few debates about how to classify the ingratiatory tactics. Some scholars classify the ingratiatory tactics by defensive and offensive tactics (Strutton et al., 1996). The defensive tactics are the ingratiatory efforts intended to make it difficult for a person to respond negatively; on the contrary, the offensive tactics are the attempts for people to proactively manipulate a target's attributions in order to get more positive responds (Strutton et al., 1996). On the other hand, some other scholars use the classification of self-focused/inwardly-focused and other-focused/targetfocused tactics (Strutton et al., 1996; Varma et al., 2006). If the tactics aim at giving the target person a good impression, they are self-focused/inwardly-focused (Varma et al., 2006). On the other hand, the otherfocused/target-focused tactics aim to make the target person feel good (Varma et al., 2006).

From this discussion, it is noted that although there are unsettled arguments towards ingratiation, there are still some consensuses existing among the literature. First, ingratiation has been generally viewed as a set of attraction-seeking behaviors (Tsang, 2015). Moreover, ingratiatory behaviors can be classified in terms of the means (e.g., different ingratiatory tactics) or the intentions (e.g., defensive and offensive). To some extent, the literature is insightful to interpret what Chinese ingratiation should be like. For example, we may conceptualize Chinese ingratiation as attractionorientated behaviors. However, it is noted that the conceptualization is derived from the Western perspective of social psychology (Tsang, 2014). Pandey (1981) already reminds us that ingratiation is culturespecific, so the consideration of cultural factors is required in the investigation on ingratiation. Moreover, many scholars have called for studying Chinese social and behavioral phenomena with Chinese indigenous concepts, such as guanxi (relation), renqing (favor) and 
mianzi (face), because these concepts are the important resources to understand the Chinese (Bian, 1994; Cheng, 1986; Cheung et al., 2008; Chow anad Ng, 2004; Ho, 1994; Hu, 1944; Hwang, 2011; King, 1992; Kipnis, 1997; Lin, 2001; Peng, 1998; Yang, 1995; Zhai, 2011). More important, if we unconditionally study social and behavioral phenomena in non-Western contexts with the Western perspective, we may distort the meanings of the phenomena (Yang, 1997). In order to overcome the limitations, this article is going to analyze Chinese ingratiation and then propose a theoretical framework from the guanxi perspective.

\section{Chinese Ingratiation: A Guanxi Perspective}

Guanxi is important and prominent in everyday life of Chinese social actors. In a broad sense, guanxi is a system of personal connections or a form of interpersonal relationship that carries long-term social obligations (Millington et al., 2005). It is formed by a specific norm rather than by all general principles among people (Hwang, 2011). In Chinese societies, guanxi is a major criterion to distinguish insider and outsider. Typically, having guanxi implies insider while no guanxi stands for outsider. According to Fei (1992), the main characteristic of guanxi is the differential mode of association. He describes Chinese social relationships is "like the ripples formed from a stone thrown into a lake, each circle spreading out from the center become more distant and at the same time more insignificant" (Fei, 1992, p. 65). In other words, individuals interact with different people with different principles and multiple standards of behaviors. People treat those who have better and closer guanxi (insider) with them much better. Therefore, Yang (1995) states that the most dynamic aspect of Chinese social interaction is relational determinism, which means "one's relationship with another person determines how one will treat or respond to that person" (Yang, 1995, p. 28).

Accordingly, a better guanxi can lead to desirable consequences-both qualitative and quantitative-to people. For example, many studies have been conducted to investigate the relationship between Chinese managerial behaviors and Chinese business leaders' employee categorization based on three criteria: Guanxi, loyalty and competence. All these studies suggest that Chinese leaders tend to allocate more valuable rewards and resources to those employees who have guanxi with them (Cheng, 1995; Cheng et al., 2002; Hu et al., 2004; Yu, 1993).

As guanxi can bring desirable consequences to Chinese people, they may attempt to establish, produce, maintain and/or improve guanxi through the strategies of guanxi management (Kipnis, 1997; Peng, 1998). There are many strategies of guanxi management, such as: Inheriting, adopting, pulling, digging into, connecting, expanding, exchanging gift, banqueting, doing favor, visiting and helping out (Bian, 2001; Kipnis, 1997; Sun, 2012; Yang, 1994). Therefore, the question here is whether ingratiation is a guanxi management strategy.

\section{Ingratiation and Guanxi Management}

To answer this question, we may need to consider the components of guanxi. According to Hwang (1987; 2012), guanxi is composed of affective and instrumental components. When affective component is dominant, it is a close guanxi, such as kinship (Hwang, 1987; 2012). On the other hand, when guanxi is dominated by instrumental component, guanxi will be distant and insignificant, such as the case of strangers (Hwang, 1987; 2012). According to Peng's (1998) study, enhancing affective component is more important than instrumental component in guanxi management in a Chinese daily life. As a result, answering whether Chinese is a guanxi management strategy requires the analysis of the relationships between ingratiation and affective component or the quality of guanxi.

Strutton et al. (1996) find that defensive ingratiation tactics (other enhancement and court and counsel) are positively related to the buyer-seller trust. They also point out that self-presentation and rendering favors can increase the affinity between humans. Moreover, the Strutton and Pelton's (1998) observation identifies ingratiation can contribute to team solidarity and strengthen team relationships, because ingratiation bolsters interpersonal attachment. Furthermore, Cooper (2005) directly points out ingratiatory humor is an affective stimulus. Moreover, the studies conducted by Tsang $(2009 ; 2015)$ indicate that ingratiation is a significant predictor of the quality of interpersonal relationship among Hong Kong youth. A similar result is also reported by Tsang et al. (2013) who study the impacts of ingratiation on the interpersonal relationship of youth in Beijing. All these studies imply that the relationship between ingratiation and affective component or the quality of interpersonal relationship should be positive. Because of this reason, ingratiation should be able to facilitate guanxi in Chinese societies so that's why it should be regarded as a guanxi management strategy.

Renqing and mianzi are the Chinese indigenous concepts closely related to guanxi. Almost all guanxi management strategies involve the use of them. Therefore, Tsang (2014) suggests that the Chinese may not only ingratiate through the uses of renqing, mianzi and attraction. As a result, Chinese ingratiation is defined as a class of behaviors that is designed to maintain, improve or promote guanxi with others through the exercises of renqing, mianzi and attraction. 


\section{Three Dimensions of Ingratiation}

According to the above definition, this article proposes that Chinese ingratiation has three dimensions-renqing orientation, mianzi orientation and attraction orientation. These three dimensions are intercorrelated, but their meanings differ from one another. Before going into the discussion of each dimension, it is necessary to highlight that that the three dimensions of ingratiation are an ideal type. It means it may not be found any ingratiatory behaviors that totally fit to one of them. However, it is meaningful to construct the ideal type, since it is helpful to interpret or predict the nature, motive, consequence of Chinese ingratiation in different situations.

The first dimension is renqing orientation. Renqing, the Chinese concept of favor, is significant to guanxi. If a person who does not know renqing, it is difficult for him or her to get along well with others in Chinese societies. In his empirical study in Taiwan, Yu (1993) indicates two forms of renqing: Instrumental renqing and affective renqing. According to his observation, instrumental renqing refers to an instrumental use for building guanxi. In contrast, affective renqing implies affective component that facilitates guanxi. Both forms of renqing can help to develop and maintain guanxi, but instrumental renqing tends to be more utilitarian than affective one. Zhang (1998, p. 72) notes, affective renqing implies considering other's feeling, caring for other's welfare and helping others etc. Instrumental renqing refers to one's doing favors for those with whom one has good relationships or someone's going through the back door to obtain desirable resources.

In addition, Hwang (1987) also indicates three different meanings of renqing. First, "renqing indicates the emotional response of an individual confronting the various situations of daily life...In psychological terminology, a person who is versed in renqing is well equipped with empathy" (Hwang, 1987, p. 953). In addition, renqing implies "a set of social norms by which one has to abide in order to get along well with other people in Chinese society" (Hwang, 1987, p. 954). Hwang (1987, p. 954) notes the norms of renqing arise two basic kinds of social behaviors:

Ordinarily, one should keep in touch with the acquaintances in one's social network, exchange gifts, greetings, or visitations with them from time to time and when a member of one's reticulum gets into trouble or faces a difficult situation, one should sympathize, offer help and 'do a renqing' for that person.

Therefore, if one cannot sympathize or do not help other people who are in need, this person will be labeled as not knowing renqing (Hwang, 2011). Finally, renqing also means the rule of social exchange (Hwang, 1987; King, 1988). According to Yang (2005), renqing, like money, can cash different resources, be quantified and be accumulated. Therefore, there are specific phenomena like 'giving renqing', 'producing renqing' and 'offering renqing' in Chinese societies. Giving renqing will provoke renqing debts, which unbalance the equilibrium of relationships, for the renqing recipients (Yang, 1995). Moreover, renqing is based on the norm of reciprocity (Sun, 2012). Therefore, it is necessary for the renqing recipients to seek opportunities to reciprocate the renqing givers. The reciprocation may be more valuable than what they received, because it can ensure all debts are repaid and the debtor can even become the creditor (King, 1988). As a result, the relationship of renqing exchange is created (Zhai, 2005). This relationship would not only help the maintenance of guanxi, but also give unexpected describable rewards to the renqing givers (Zhai, 2011).

Accordingly, it is possible for the Chinese to ingratiate by utilizing renqing (instrumental renqing). In turn, it may enhance the affective renqing in order to facilitate guanxi. Two forms of practice of renqingoriented ingratiation are identified here. First, ingratiatiors may try hard to convince target persons that they are versed in renqing, because it will let the target persons perceive them favorably. Second, ingratiatiors may also find opportunities to give renqing (e.g., doing favor, helping out and giving gift) to the target persons, because it can create a renqing debt to the targets. This does not only help the guanxi management, but also offer unpredictable but describable consequences to them.

The second dimension of Chinese ingratiation is mianzi (the Chinese concept of face) orientation. According to $\mathrm{Hu}$ (1944) and King (2006), mianzi is composed of social face (mianzi) and moral face (lian). Social face represents one's reputation and status and moral face represents human's morality. Moreover, Cheng (1986) notes social face implies the maximum of individual's dignity, social recognition and social esteem, while moral face is the minimum. In other words, having social face ensures having moral face, but having moral face does not guarantee of having social face (Zhai, 2005). Therefore, Chang and Holt (1994, p. 99) claim social face "reflects one's reputation achieved and maintained through the scrutiny of others, with the standard of acknowledgment reflecting not only social values, but moral values as well." As a result, social face is more emphasized than moral face in Chinese societies (Zhai, 2005). Because of this reason, Chinese ingratiation may be social-oriented rather than moral-oriented.

In fact, mianzi very important to the Chinese. Lin (1939) analogizes mianzi is the most powerful Muse ruling over China. This is because having mianzi can 
increase one's "purchasing power" (King, 2006). Moreover, mianzi can ensure smooth social interaction (Chang and Holt, 1994). The research conducted by Chow and $\mathrm{Ng}$ (2004) shows that those who have mianzi easily develop guanxi with others. One possible way for people to gain mianzi is through ingratiation (Chu, 2006). They can increase and promote their mianzi through self-presentation, self-promotion or namedropping. In addition to the self-focused approach, the Chinese may ingratiate through giving and saving the target persons' mianzi (e.g. other-enhancement, selfdepreciation, instrumental dependency, court and counsel and conformity). When a person gives or saves another person's mianzi, renqing exchange will also be created (Zhai, 2011). Furthermore, if a person does not save others' mianzi appropriately, this person will be regarded as churl and, more seriously, lose his or her own mianzi (Ho, 1994). As a result, if people want to have better guanxi with others, they have to consider other's mianzi (Tsang, 2014).

The last dimension of Chinese ingratiation is attraction orientation. Actually, the existing literature has emphasized this dimension of ingratiation. This can be reflected by the literature, which is based on the Western perspective, discussed in the previous section. The literature also tends to support that successful ingratiation can really make oneself becomes more attractive (Tsang, 2015). Thus, some people may call ingratiation as an attraction-seeking behavior (Jones, 1964).

According to the literature, four reasons why successful ingratiation can turn someone to be more attractive can be summarized as the follows. First, ingratiation can let the target know the actor's positive characteristics. When an ingratiatior self-presents or selfpromotes, he or she is trying to convey that he or she has positive characteristics and no negative or undesirable traits (Jones and Wortman, 1973). Therefore, the target may view him or her more favorably, because of the artificial image (Liden and Mitchell, 1988). Second, ingratiatory tactics, such as conformity, can increase the similarities between two persons. According to the similarity-attraction paradigm, mutual attractiveness can be enhanced by similarities among people (Byrne, 1971). In fact, "people like those whose values and beliefs appear to be similar to their own" (Jones and Wortman, 1973 , p. 16). Therefore, it is possible that targets like the ingratiatiors because the ingratiatiors present similar opinions, attitudes and behaviors to theirs (Strutton et al., 1995). The third reason is the selfesteem of target persons may be fostered. According to Tedeschi and Melburg (1984), other enhancement leads ingratiatiors to become more likeable, because it does not only give positive evaluations to the targets but also bolster their self-esteem. Finally, ingratiation can make the target persons perceive that the ingratiatiors like or respect them. For example, when a target is flattered, praised and complimented by someone, he or she may believe this person likes him or her (Jones and Wortman, 1973). According to the balance theory, liking will be reciprocated (Strutton and Pelton, 1998). Therefore, the target will be motivated to begin liking this person. When the ingratiatior successfully attracts to the target person, the relationship between them will be enhanced. Liden and Mitchell (1988) indicate that successful ingratiation can increase the quality of interaction and exchange relationship between the ingratiatior and the target person.

It has to be noted that although each dimension of Chinese ingratiation has its own characteristics, they are inter-correlated and difficult to be distinguished in a real life. For example, when person A gives a gift to person $\mathrm{B}$, it is possible that A's attractiveness is increasing in the eyes of B. At the same time, B does receive A's renqing. In addition, the gift may also imply that $\mathrm{A}$ is giving mianzi to $\mathrm{B}$. Therefore, we can interpret every ingratiatory behavior as attraction-oriented, renqingoriented, mianzi-oriented or both of them. However, we must remember that the ultimate intention of Chinese ingratiation is to manage guanxi. The characteristics of the three dimensions are summarized in the Table 1.

\section{The Patterns of Chinese Ingratiation}

The major features of guanxi are self-centered and the boundary of guanxi is ambiguous and flexible (Fei, 1992). Therefore, everyone has to carefully consider the following questions before the social interaction with others: Which kind of guanxi is between him or her and others? How strong is their guanxi? (Hwang, 1987). In general, people classify guanxi with others into family, familiar persons (e.g., neighbors, colleagues or classmates) and strangers (Yang, 1995). The importance and intimacy of each guanxi is different (Sun, 2012). Family is a permanent and stable guanxi; familiar persons are unstable but necessary between people; and strangers are unstable and not necessary (Hwang, 1987). Theoretically speaking, as a result, ingratiation may be more likely to target to familiar persons and less within strangers in a normal situation (Fig. 1). This pattern may change in special contexts. For example, if a person wants to create a new social tie with a stranger for any purpose, his or her ingratiatory intention toward that stranger may become stronger than the ingratiatory intention toward the familiar persons.

Furthermore, each type of ingratiation would occur differently in different types of guanxi (Fig. 2). Individual seeks to influence familiar persons by the uses of renqing and mianzi (Hwang, 1987; 2012; Yang, 1995). As a result, renqing and mianzi orientations should be more likely to occur than attraction orientation 
in this type of guanxi. In family, everyone has to do their best for supporting to each other (Hwang, 1987; 2012; Yang, 1995). Therefore, renqing practice may not be highly emphasized in this type of guanxi compared with familiar persons. On the other hand, mianzi is functional within inside and outside family (Yang, 1995). In addition, attraction would also be significant to family. For example, a mother has two sons, C and D. C always conforms and gives gifts to her mother, but $\mathrm{E}$ never does. Therefore, this mother likes and treats $\mathrm{C}$ better than $\mathrm{D}$, because she thinks $\mathrm{C}$ is more dutiful. Because of these kinds of reasons, attraction and mianzi orientations should be more likely to occur in family instead of renqing orientation. Renqing and mianzi orientations should be less likely to occur in strangers than attraction orientation. It is because people do not need to concern about renqing and mianzi while interacting with strangers (Hwang, 1987; Yang, 1995). On the contrary, everyone should want to be attractive to other people no matter what guanxi they are.

Table 1. The characteristics of the three types of ingratiation

\begin{tabular}{|c|c|c|c|}
\hline & \multicolumn{3}{|l|}{ Dimensions } \\
\hline & Renqing orientation & Mianzi orientation & Attraction orientation \\
\hline Nature & $\begin{array}{l}\text { Convince the target person that } \\
\text { the ingratiatior is versed in renqing } \\
\text { Giving renqing to the target person }\end{array}$ & $\begin{array}{l}\text { Increase the ingratiatior's own mianz } \\
\text { Giving and saving the target } \\
\text { person's mianzi }\end{array}$ & $\begin{array}{l}\text { Let the target knows the ingratiatior's } \\
\text { own positive side } \\
\text { Increase the similarities between the target } \\
\text { and the ingratiatior } \\
\text { Foster the self-esteem of the target person } \\
\text { Convince the target person that the } \\
\text { ingratiatior likes or/and respect him or her }\end{array}$ \\
\hline Motive & Renqing practice & $\begin{array}{l}\text { Saving and enhancing one's } \\
\text { (ingratiatior or target or both) mianzi }\end{array}$ & $\begin{array}{l}\text { Increase the one's attractiveness in the eyes } \\
\text { of the target person }\end{array}$ \\
\hline Consequence & $\begin{array}{l}\text { Guanxi will be kept or improved } \\
\text { through renqing exchange }\end{array}$ & $\begin{array}{l}\text { The quality of guanxi will be better } \\
\text { because everyone considers others' } \\
\text { mianzi }\end{array}$ & $\begin{array}{l}\text { Guanxi will be improved or maintained } \\
\text { because the interaction and exchange } \\
\text { relationship are improved }\end{array}$ \\
\hline
\end{tabular}

\begin{tabular}{ll}
$\begin{array}{l}\text { High ingratiatory } \\
\text { intention }\end{array}$ & $\begin{array}{l}\text { Low ingratiatory } \\
\text { intention }\end{array}$ \\
\hline
\end{tabular}

$\begin{array}{lll}\text { Familiar persons } & \text { Family } & \text { Strangers }\end{array}$

Fig. 1. Ingratiatory intention in a normal situation

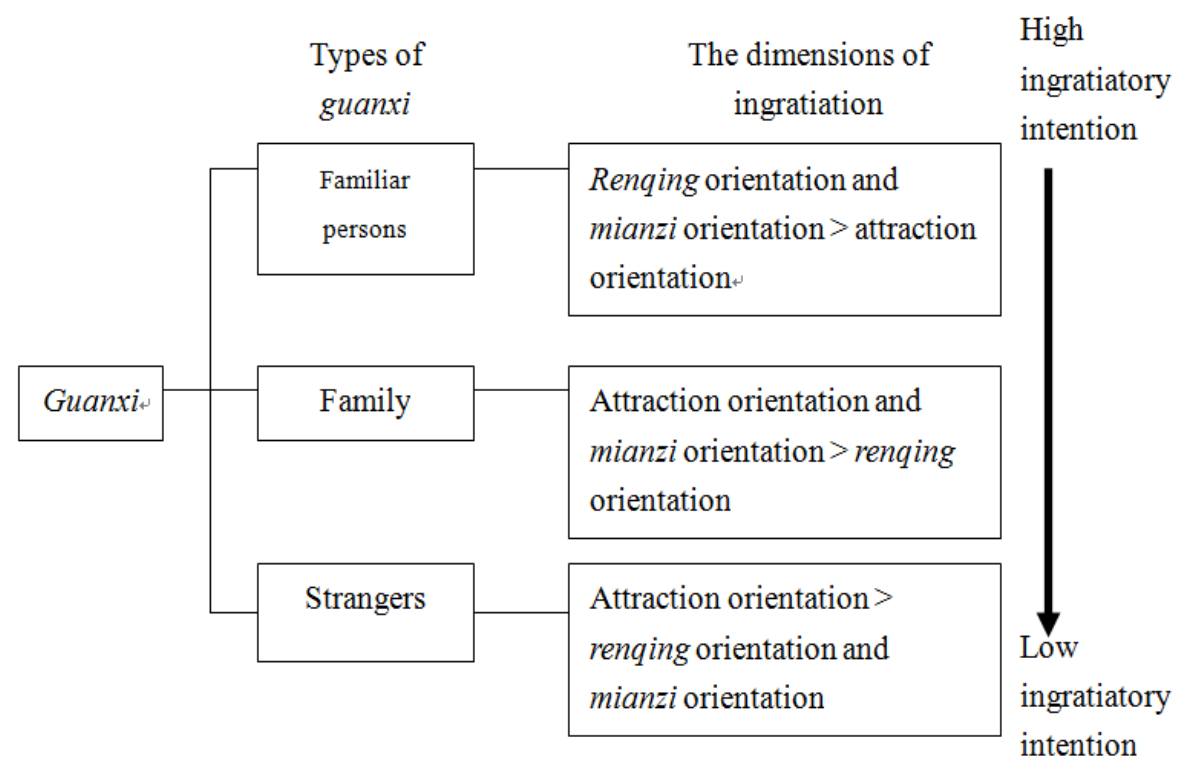

Fig. 2. The patterns of Chinese ingratiation 


\section{Conclusion}

There are a lot of researchers who have studied ingratiation since 1960s. Nevertheless, everyone seems to lack interest to study Chinese ingratiation. Although some people have studied related topics, they only adopt the Western viewpoints. However, Chinese ingratiation should differ from the West. This is because ingratiation is viewed as an attractionseeking behavior in the Western societies, while it is viewed as a guanxi management strategy in Chinese societies (Tsang, 2014). Therefore, this article tries to provide a theoretical framework based on the guanxi perspective to further studies.

First, Chinese ingratiation is defined as a set of social behaviors designed to maintain, improve or promote guanxi with others through the uses of renqing, mianzi and attraction. In this sense, Chinese ingratiation includes three orientations, including renqing, mianzi and attraction orientations. Therefore, Chinese ingratiation is different from the Western ingratiation, which only emphasizes the attraction orientation rather than the other two dimensions. Although attraction orientation exists in both Western and Chinese contexts, the ultimate goals are different. Attraction orientation of Western ingratiation may not aim to produce and maintain guanxi. It may only be attraction-seeking. On the other hand, attraction orientation of Chinese ingratiation tends to focus on guanxi management.

Furthermore, Chinese ingratiation has two features: (1) The ingratiatory intention would decrease progressively along the direction from familiar persons to family and, in turn, to strangers (2) renqing and mianzi orientations would be more likely to occur than attraction orientation within familiar persons; attraction and mianzi orientations would be more likely to occur than renqing ingratiation within family; attraction orientation would be more likely to occur than renqing and mianzi orientations within strangers.

Nevertheless, it is only a theoretical analysis. Currently, we are still missing empirical evidences to support it. Therefore, empirical studies are required to test this framework in the future. To achieve this goal, quantitative and qualitative studies are necessary. For quantitative research, we should first develop reliable and valid instruments to measure and assess Chinese ingratiation. After that, we should study Chinese ingratiation with different populations in every Chinese society (e.g., China, Taiwan, Hong Kong, Singapore) as much as possible. Finally, we can know how well this Chinese ingratiation framework is through statistically modeling. Moreover, by using qualitative methods, such as interview and participant observation, it is possible for us to understand how
Chinese interprets and practices ingratiation in real setting. Through examining their interpretation and practices, we may then conclude whether there are three orientations of ingratiation exists, how Chinese ingratiation operates, what the causes and consequences of Chinese ingratiation in real social setting, how Chinese people perceive ingratiation and the like.

\section{Ethics}

This article is original and contains unpublished material. The corresponding author confirms that all of the other authors have read and approved the manuscript and no ethical issues involved.

\section{References}

Aryee, S., Y.A. Debrah and Y.W. Chay, 1993. An investigation of ingratiation as a career management strategy: Evidence from Singapore. Int. J. Hum. Resource Manage., 4: 191-212. DOI: $10.1080 / 09585199300000010$

Bian, Y., 1994. Work and Inequality in Urban China. 1st Edn., SUNY Press, Albany, ISBN-10: 0791418014, pp: 286.

Bian, Y., 2001. Guanxi Capital and Social Eating in Chinese Cities: Theoretical Models and Empirical Analyses. In: Social Capital: Theory and Research, Lin, N., K. Cook and R.S. Burt (Eds.), Aldine de Gruyter, New York, pp: 275-295.

Bohra, K.A. and J. Pandey, 1984. Ingratiation toward strangers, friends and bosses. J. Soc. Psychol., 122: 217-222. DOI: 10.1080/00224545.1984.9713483

Byrne, D., 1971. The Attraction Paradigm. 1st Edn., Academic Press, New York, pp: 474.

Carnegie, D., 1936. How to win Friends and Influence People. 1st Edn., Pocket Books, New York,

Chang, H. and G.R. Holt, 1994. A Chinese Perspective on Face as Inter-Relational Concern. 1st Edn., State University of New York, New York.

Cheng, B.S., 1995. Differential model of association and Chinese organizational behaviors. Indigenous Psychol. Res. Chinese Societies, 3: 142-219

Cheng, B.S., J.L. Farh, H.F. Chang and W.L. Hsu, 2002. Guanxi, zhongcheng, competence and managerial behavior in the Chinese context. J. Chinese Psychol., 44: 151-162.

Cheng, C.Y., 1986. The concept of face and its confucian roots. J. Chinese Philosophy, 12: 329-348. DOI: 10.1111/j.1540-6253.1986.tb00102.x

Cheung, F.M., W. Fan, S.F. Cheung and K. Leung, 2008. Standardization of the cross-culture [Chinese] personality assessment inventory for adolescents in Hong Kong: A combined emic-etic approach to personality assessmen. Acta Psychol. Sinica, 40: 839-852. 
Chow, I.H.S. and I. Ng, 2004. The characteristics of Chinese personal ties (guanxi): Evidence from Hong Kong. Organiz. Stud., 25: 1075-1093. DOI: $10.1177 / 0170840604045092$

Chu, R.L., 2006. Social interactions among the Chinese: On the issue of face. Chinese Soc. Psychol. Rev., 2: 79-106.

Cooper, C.D., 2005. Just joking around? Employee humor expression as an ingratiatory behavior. Acad. Manage. Rev., 30: 765-776. DOI: 10.5465/AMR.2005.1837887

Fei, X., 1992. From the Soil: The Foundations of Chinese Society. 1st Edn., University of California Press, Berkeley, ISBN-10: 0520077962, pp: 170.

Ho, D.Y.F., 1994. Face Dynamics: Form Conceptualization to Measurement. In: The Challenge of Facework: Cross-Cultural and Interpersonal Issues, Ting-Toomey, S. (Ed.), State University of New York, New York, ISBN-10: 079141633X, pp: 269-286.

Hu, H.C., 1944. The Chinese concepts of "face". Am. Anthropol., 46: 45-64.

DOI: 10.1525/aa.1944.46.1.02a00040

$\mathrm{Hu}$, H.H., W.L. Hsu and B.S. Cheng, 2004. Reward allocation decisions of Chinese managers: Influence of employee categorization and allocation context. Asian J. Soc. Psychol., 7: 221-232.

DOI: 10.1111/j.1467-839x.2004.00146.x

Hwang, K.K., 1987. Face and favor: The Chinese power game. Am. J. Sociol., 92: 944-974. DOI: $10.1086 / 228588$

Hwang, K.K., 2011. Foundations of Chinese Psychology: Confucian Social Relations. 1st Edn., Springer, New York, ISBN-10: 1461414393, pp: 378.

Jones, E.E., 1964. Ingratiation: A Social Psychological Analysis. 1st Edn., Appleton-Century-Crofts, New York, pp: 211.

Jones, E.E. and C. Wortman, 1973. Ingratiation: An Attributional Approach. 1st Edn., General Learning Press, Morristown, pp: 55.

King, A.Y.C., 1988. An Analysis of Renqing in Interpersonal Relation. In: Chinese Psychology, Yang, K.S. (Ed.), Gui Guan Press, Taibei, pp: 75-104.

King, A.Y.C., 1992. Guanxi and network construction: A sociological analysis. Economy Society, 8: 143-157.

King, A.Y.C., 2006. Face, shame and the analysis of behavior patterns of the Chinese. Chinese Soc. Psychol. Rev., 2: 48-64.

Kipnis, A., 1997. Producing Guanxi: Sentiment, Self and Subculture in a North China Village. 1st Edn., Duke University Press, Burham, ISBN-10: 0822318733, pp: 226.

Liden, R.C. and T.R. Mitchell, 1988. Ingratiatory behaviors in organizational settings. Acad. Manage. Rev., 13: 572-587.

DOI: $10.5465 / A M R .1988 .4307430$
Lin, N., 2001. Guanxi: A Conceptual Analysis. In: The Chinese Triangle of Mainland China, Taiwan and Hong Kong: Comparative Institutional Analyses, So, A.Y., N. Lin and D. Poston (Eds.), Greenwood Press, Westport, pp: 153-166.

Lin, Y., 1939. My Country and my People. 1st Edn., W. Heinemann, London, pp: 440.

Millington, A., M. Eberhardt and B. Wilkinson, 2005. Gift giving, guanxi and illicit payments in buyersupplier relations in China: Analysing the experience of UK companies. J. Bus. Eth., 57: 255-268. DOI: 10.1007/s 10551-004-6712-y

Myers, D., 2013. Social Psychology. 1st Edn., McGrawHill, San Francisco,

Pandey, J., 1981. Ingratiation tactics in India. J. Soc. Psychol., 113: 147-148. DOI: $10.1080 / 00224545.1981 .9924364$

Peng, S., 1998. Guanxi in trust: An indigenous study of Chinese interpersonal trust. Ph.D Thesis, University of Hong Kong, Hong Kong.

Rosenfeld, P., R.A. Giacalone and C.A. Riordan, 1995. Impression Management in Organizations: Theory, Measurement, Practice. 1st Edn., Routledge, London, ISBN-10: 0415126797, pp: 219.

Strutton, D. and L.E. Pelton, 1998. Effects of ingratiation on lateral relationship quality within sales team settings. J. Bus. Res., 43: 1-12. DOI: 10.1016/S0148-2963(97)00075-1

Strutton, D., L.E. Pelton and J.R. Lumpkin, 1995. Sex differences in ingratiatory behavior: An investigation of influence tactics in the salespersoncustomer dyad. J. Bus. Res., 34: 34-45. DOI: 10.1016/0148-2963(94)00040-L

Strutton, D., L.E. Pelton and J.F.J. Tanner, 1996. Shall we gather in the garden: The effect of ingratiatory behaviors on buyer trust in salespeopl. Indust. Market. Manage., 25: 151-162. DOI: 10.1016/0019-8501(95)00074-7

Sun, C.T.L., 2012. Themes in Chinese Psychology. 2nd Edn., Cengage Learning Asia, Singapore, ISBN-10: 9814416614, pp: 296.

Tedeschi, J.T. and V. Melburg, 1984. Impression Management and Influence in the Organization. In: Research in the Sociology of Organization, Bacharach, S.B. and E.J. Lawler (Eds.), JAI Press, Greenwich, pp: 31-58.

Tsang, K.K., 2009. Ingratiation among Hong Kong Youth. Int. J. Adolescence Youth, 15: 277-288. DOI: $10.1080 / 02673843.2009 .9748033$

Tsang, K.K., 2011. A theoretical framework of guanxi dynamics. Chinese J. Sociol., 31: 96-115.

Tsang, K.K., 2014. Chinese Ingratiation: A Social Psychological Analysis from Guanxi Perspective. Lambert Academic Publishing, Saarbrucken, ISBN-10: 3659523402, pp: 96. 
Tsang, K.K., 2015. Ingratiation, attractiveness and interpretational relation of youths. Res. Psychol. Behav. Sci., 3: 1-4. DOI: 10.12691/rpbs-3-1-1

Tsang, K.K., T.K. Ng and Y. Wang, 2013. Ingratiation, renqing, mianzi and attraction: A guanxi perspective. Scientific J. Pure Applied Sci., 2: 95-105.

Varma, A., S.M. Toh and S. Pichler, 2006. Ingratiation in job applications: Impact on selection decision. J. Manage. Psychol., 21: 200-210.

DOI: $10.1108 / 02683940610659551$

Yang, C.F., 2005. Are Chinese really "collectivists"? Exploring the relations of culture, values and individual. Chinese Soc. Psychol. Rev., 1: 55-93.

Yang, K.S., 1981. Social orientation and individual modernity among Chinese students in Taiwan. J. Soc. Psychol., 113: 159-170. DOI: $10.1080 / 00224545.1981 .9924368$

Yang, K.S., 1995. Chinese Social Orientation: An Integrative Analysis. In: Chinese Societies and Mental Health, Lin, T.Y., W.S. Tseng and E.K. Yeh (Eds.), Oxford University Press, Hong Kong, pp: 19-39.
Yang, K.S., 1997. Indigenising Westernised Chinese Psychology. In: Working at the Interface of Cultures: Eighteen Lives in Social Science, Bond, M.H. (Ed.), Routedge, London, pp: 62-84.

Yang, M.M.H., 1994. Gifts, Favors and Banquets: The Art of Social Relationships in China. Cornell University Press, Ithaca, ISBN-10: 080149592X, pp: 370 .

$\mathrm{Yu}$, B.C., 1993. Instrumental renqing and affective renqing: A case study of a public-enterprise in Taiwan. J. Soc. Sci., 41: 87-120.

Zhai, X., 2005. The Reproduction of Renqing, Mianzi and Power. 1st Edn., Peking University Press, Peking.

Zhai, X., 2011. The Principles of Chinese Guanxi: TimeSpace Order, Life Desire and their Changes. 1st Edn., Peking University Press, Peking.

Zhang, Z., 1998. The role of guanxi and renqing in Chinese reward allocation. Ph.D Thesis, Univesrity of Hong Kon, Hong Kong. 